\title{
Developments
}

\section{The German Stem Cell Act}

\author{
By Jochen Taupitz ${ }^{*}$
}

\begin{abstract}
The article describes the original Stem Cell Act, the reform discussion following its enactment and the reform of the Act adopted by the German Bundestag on 11 April 2008.
\end{abstract}

\section{A. The Legal Position under the Act of 28 June 2002}

\section{Introduction}

In 2000, the German Researcher Oliver Brüstle officially applied for support from the Deutsche Forschungsgemeinschaft (DFG) (German Research Foundation, GRF) for a research program that needed the importation of human embryonic stem cells from abroad. ${ }^{1}$ This led to a strong debate about the ethical and legal acceptability of the importation of human embryonic stem cells because their production requires the "consumption" of the embryos. While the Embryo Protection Act (EPA) of 13 December 1990, in force since 1 January 1991, ${ }^{2}$ prohibits such a use of embryos in Germany, it does not include a provision regarding the importation of stem cells created by such means. The lack of a prohibition of importation was considered by some as an implicit permission to import and by others as an unintentional loophole within the Embryo Protection Act.

The German Research Foundation was asked by political circles to delay its decision concerning the request of Brüstle, so that the Parliament could have the possibility to make up ist mind. The GRF delayed its decision on the Brüstle request. Following this the

\footnotetext{
"Professor of Civil Law, Law of Civil Procedure, Private International Law and Comparative Law at the University of Mannheim; Managing Director of the Institute for German, European and International Medical Law, Public Health Law and Bioethics of the Universities of Heidelberg and Mannheim. Email: taupitz@rumms.unimannheim.de.

${ }^{1}$ Brüstle had already given notice of his application some months earlier; therefore the discussion about the importation of embryonic stem cells started before 2000 .

${ }^{2}$ See BGBL. I:2746 (1990).
} 
$\mathrm{GRF}^{3}$, as along with two newly founded political advisory boards gave their opinions on the matter. While the committee of enquiry "Recht und Ethik der modernen Medizin" ("law and ethics of modern medicine"), deployed by the German Bundestag on 24 March 2001, spoke out against the importation of embryonic stem cells, ${ }^{4}$ the majority of members of the "Nationaler Ethikrat" ("National Ethics Council"), deployed on 2 May 2001 through the German Government, demanded a time-limited and strict ruling allowing the importation of embryonic stem cells. ${ }^{5}$

On 30 January 2002 the German Bundestag discussed three proposals with which a formal legislation procedure was to be set up:

The Proposal by the Members of Parliament Wodarg a.o. held, "in light of the protection of the dignity of embryos and the Embryo Protection Act," that there should be a prohibition of the importation of embryonic stem cells without exception. ${ }^{6}$

The Proposal by the Members of Parliament Flach, Reiche, Hintze a.o. pleaded for the possibility of importation, as long as the imported embryonic stem cells came from leftover (supernumerary) embryos that were donated for high-ranking scientific research. A commission would perform a scientific and ethical investigation in order to approve the importation. $^{7}$

The Proposal by the Members of Parliament Böhmer, von Renesse, Fischer a.o., intended for legislation against the consumption of further embryos in order to gain embryonic stem cells. The importation of stem cells was to be only allowed under strict measures for scientific research. ${ }^{8}$

The last Proposal received the majority of votes and was the foundation of the Stem Cell Act, which was decided on 28 June 2002.

The Act, which ensures the protection of embryos in connection with the importation and use of human embryonic stem cells (Stem Cell Act, SCA) (Gesetz zur Sicherstellung des

\footnotetext{
${ }^{3}$ See Deutsche Forschungsgemeinschaft [German Research Foundation], Humane embryonale Stammzellen: Stellungnahme vom 19. März 1999, in HUMANGENOMFoRsCHUNG - PeRSPEKTIVEN UND KONSEQUeNZEN 3 (2000).

${ }^{4}$ See Deutscher Bundestag: Drucksachen und Protokolle [BT] 14/7546.

5 See Nationaler Ethikrat, Zum import menschlicher embryonaler Stammzellen (2002); Manuela Brewe, EMBRYONENSCHUTZ UND STAMMZELLGESETZ 54 (2006).

${ }^{6}$ BT $14 / 8101$

${ }^{7}$ See BT $14 / 8103$.

${ }^{8}$ See BT $14 / 8102$
} 
Embryonenschutzes im Zusammenhang mit Einfuhr und Verwendung menschlicher embryonaler Stammzellen - Stammzellgesetz, StZG), ${ }^{9}$ entered into force on 1 July 2002. It governs the importation and the use of human embryonic stem cells (hES cells).

The importation and the use of embryonic stem cells are in principle prohibited ( $\$ 4$ (1) in conjunction with $\$ 1$ no. 2 SCA). Under particular circumstances, however, importation and use are exceptionally permissible ( $\$ 4(2)$ in conjunction with $\S 1$ no. 3 SCA). According to $\S 1$ SCA, it is the purpose of the Stem Cell Act

in consideration of the State's obligation to respect and protect human dignity and the right to life and to guarantee the freedom of research ... 1. to prohibit, in principle, the importation and use of embryonic stem cells, 2. to prevent German demand from causing the derivation of embryonic stem cells or the production of embryos with the aim of deriving embryonic stem cells, and 3 . to determine the requirements to exceptionally permit the importation and use of embryonic stem cells for research purposes only.

Stem cells, under $\S 3$ no. 1 SCA, are "all human cells which have the potential to multiply by cell division if in a suitable environment and which by themselves or through their daughter cells are capable, under favourable conditions, of developing into specialised cells, but not into a human being (pluripotent stem cells)." Embryonic stem cells, under $\S 3$ no. 2 SCA, are "all pluripotent stem cells derived from embryos which have been extracorporeally produced and have not been used to bring about pregnancy or which have been taken from a woman before the completion of nidation." In this context, an embryo is "any human totipotent cell which has the potential to divide and to develop into a human being if the necessary conditions prevail" ( $\$ 3$ no. 4 SCA). It is irrelevant whether the totipotent cell was itself taken from an embryo (unlike in $\S 8$ of the Embryo Protection Act).

\section{Protection of Living Embryos Abroad: Cutoff Date Provision (Key Date Provision)}

The central concern of the Act is the provision which proceeds from the derivation (= procurement) of stem cells from embryos and is aimed at the protection of living embryos abroad. Under $\$ 4$ (2) no. 1 (a) SCA, embryonic stem cells may be imported and utilised, if at all, if "the competent agency has satisfied itself that . . . the embryonic stem cells were

\footnotetext{
${ }^{9}$ See BGBL. I:2277-2280 (2002).
} 
derived before 1 January $2002^{10}$ in the country of origin in accordance with relevant national legislation there and are kept in culture or are subsequently stored using cryopreservation methods (embryonic stem cell line)." This "cutoff date provision" or "key date provision" intends to prevent embryos available abroad from being utilised for the purposes of German research. In other words, the prohibition of an "instrumental use" of embryos according to §2 EPA is also applied to the derivation of embryonic stem cells abroad. $^{11}$

III. Disapproval or Prevention of Particularly Reprehensible Acts in Connection with the Derivation of Stem Cells

$\S 4$ (2) SCA contains further provisions relating to the derivation of the hES cells. They are discernibly based on the consideration that the derivation of stem cells may not be preceded by any act regarded as particularly reprehensible by the legislator. ${ }^{12}$ They are therefore based on the ethical but constitutionally questionable ${ }^{13}$ prohibition of harvesting the fruit of a poisonous tree. ${ }^{14}$ The restrictions would only provide independent futureoriented protection for embryos (located abroad) if the cutoff date provision were repealed.

Under $\$ 4$ (2) no. 1 (b) SCA, it must be confirmed to the satisfaction of the authorising agency that the embryos from which the stem cells were derived were created by way of medically assisted extracorporeal fertilisation for the purpose of effecting a pregnancy. This excludes, inter alia, the importation and use of hES cells which come from embryos created by way of cell nuclear transfer ("therapeutic cloning", "Dolly" method). For this method does not consist in a "fertilisation." The requirement of extracorporeal fertilisation prevents the importation of stem cells that come from embryos that were created by way of an intracorporeal fertilisation process (insemination or gamete intrafallopian transfer) and were removed from the mother again before nidation by way of uterine lavage, at the mother's wish. In addition, the allowed stem cells must come

\footnotetext{
${ }^{10}$ On the reform of the statute, see Section C. infra.

${ }^{11}$ Legislative rationale of the draft Stem Cell Act of 27 February 2002, BT 14/8394 at 8; see also Christian Starck, Embryonic Stem Cell Research according to German and European Law, 7 GeRMAN LAW JOURNAL 625, 641 (2006).

${ }^{12}$ See Taupitz, Erfahrungen mit dem Stammzellgesetz, 62 JURISTENZEITUNG 113 (2007).

${ }^{13}$ On the unconstitutionality of the restrictions of the Stem Cell Act going beyond the cutoff date provision, see, in addition to those named infra note 25: Wolfrum, Schriftliche Stellungnahme of 7 March 2002, des Ausschusses für Bildung, Forschung und Technikfolgenabschätzung des Deutschen Bundestages, BT 14/574; Löwer, Schriftliche Stellungnahme of 8 March 2002, des Ausschusses für Bildung, Forschung und Technikfolgendabschätzung des Deutschen Bundestages BT 14/574; Jochen Taupitz, Alternativlosigkeit als Voraussetzung der Forschung mit embryonalen Stammzellen, in JAHRBUCH FÜR WISSENSCHAFT UND ETHIK 335, 341 (2003) (with further references); see also infra II 5.
}

${ }^{14}$ See Taupitz, supra note 12. 
from embryos created for the purpose of bringing about a pregnancy, without ultimately being used for this purpose (known as supernumerary embryos). In any case, these embryos had no chance of survival. In contrast, the importation and use of stem cells from embryos created for the purpose of deriving stem cells or for the purpose of research are not permissible. Further on, the decision to reject the embryos is not to have been made for reasons based on the embryos themselves. As a consequence, the importation and use of stem cells from embryos that were rejected on the basis of pre-implantation diagnosis (PID) are not permissible. And finally, no payment or other non-cash benefit is allowed to be granted or promised for the permission to use the embryos to derive stem cells ( $\$ 4$ (2) no. $1 \mathrm{c}$ ) SCA). Thus, on the one hand commercialisation is avoided, and on the other hand it is also ensured that the decision of the genetic parents to permit the embryo to be used for research was not made in a situation of financial distress.

\section{Protection of Other Provisions of German Law}

$\S 4$ (2) SCA contains a third group of requirements, which protect other prohibitions within German law: The competent agency must have satisfied itself that other legal provisions, in particular those of the German Embryo Protection Act, do not conflict with the importation or utilization of embryonic stem cells. ${ }^{15}$ In addition, approval must be refused if the derivation of the stem cells manifestly occurred in contradiction to fundamental principles of the German legal system (§4 (3) sentence $1 \mathrm{SCA}) .{ }^{16}$ The refusal of approval may, however, expressly not be justified with the argument that the stem cells were derived from human embryos ( $\$ 4(3)$ sentence 2 SCA). Since hES cells are by definition derived from human embryos, this provision serves to harmonise the Stem Cell Act with §2 EPA (prohibition of the use of embryos other than to effect a pregnancy). This shows that the legislator does not regard the (past) use of embryos other than to effect a pregnancy as one of the particularly reprehensible acts mentioned under A.III., that is, it does not regard the use of embryos to derive stem cells in itself as a violation of human dignity. ${ }^{17}$

\section{Restriction of Work Using Embryonic Stem Cells in Germany}

The importation and the use of embryonic stem cells may be approved only for research purposes ( $\$ 4(2)$ SCA), and only if "the requirements of $\S 5$ SCA have been complied with and the research project is ethically justifiable in this sense" (§6 (4) no. 2 SCA). ${ }^{18} \S 5$ SCA has two partial requirements: Firstly, under $\S 5$ no. 1 SCA research work on embryonic stem

\footnotetext{
${ }^{15}$ See BREWE, supra note 5, at 194-195 (providing a more detailed treatment).

${ }^{16}$ See id. (providing a more detailed treatment).

${ }^{17}$ See Dederer, Verfassungskonkretisierung im Verfassungsneuland-das Stammzellgesetz, 58 JURISTENZEITUNG 986, 993 (2003)

${ }^{18}$ Christian Honecker, Was heißt "ethisch vertretbar"?, in JAHRBUCH FÜR WISSENSCHAFT UND ETHIK 361 (2003).
} 
cells may only be conducted "if it has been shown by giving scientific reasons that such research serves eminent research aims to gain scientific knowledge in basic research or to extend diagnostic, preventive or therapeutic methods to be applied to humans." This criterion of eminence primarily relates to the aims of the intended research. ${ }^{19}$

Secondly, under $\S 5$ no. 2 SCA it must have been shown by giving scientific reasons that

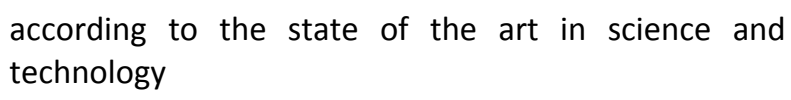

a) the questions to be studied in the research project concerned have been clarified as far as possible in in vitro models using animal cells or in animal experiments and

b) the scientific knowledge to be gained from the research project concerned can only be expected to be achieved by using embryonic stem cells.

This second criterion is directed towards the means employed for this purpose. On the one hand, there must be sufficient prior clarification concerning the question one wishes to answer in experiments on animals or animal cells (so that it is "now" necessary to continue research with human cells). On the other hand, it must be shown that the knowledge to be gained cannot be achieved in any other way than by research using human embryonic stem cells (for example by research using adult cells or cells from umbilical cord blood).

Both partial requirements may be reduced to the (linked) aspects of necessity and subsidiarity, possible to summarise briefly under the term "lack of alternatives." 20

The provisions described above do not, therefore, refer in a past-oriented manner to the circumstances of the creation, which took place abroad. Instead, in a future-oriented manner, they provide the additional requirements which are to be complied with in Germany. These provisions, which also restrict research, apply - as does the whole Stem Cell Act - (only) to stem cells, that is, to cells that as such are not totipotent and therefore

\footnotetext{
${ }^{19}$ See BREWE, supra note 5, at 199 (providing a more detailed treatment); Hans-Georg Dederer, Hochrangigkeit von Zielen der Stammzellforschung im Lichte des Grundgesetzes, in JAHRBUCH FÜR WISSENSCHAFT UND ETHIK 305 (2003).

${ }^{20}$ See BREWE, supra note 5, at 199 (providing a more detailed treatment); Jochen Taupitz, Alternativlosigkeit als Voraussetzung der Forschung mit embryonalen Stammzellen, in JAHRBUCH FÜR WISSENSCHAFT UND ETHIK 335 (2003); Jochen Taupitz, Der Schutz embryonaler Stammzellen durch das Stammzellgesetz, GENTECHNIK \& RECHT 11,12 (2003).
} 
are generally held not to enjoy any protection of human dignity and life. ${ }^{21}$ In the opinion of the legislator, the research restrictions which are laid down in the Act are justified by the fact, that embryonic stem cells may not "from the ethical point of view" be regarded in the same way as every other form of human material, since in order to derive them it was necessary to destroy embryos. ${ }^{22}$ The "fruit of the poisonous tree" is therefore not to be used at will; its use is even to be "reduced to a minimum." ${ }^{23}$ But ethical misgivings as such cannot justify a restriction of the freedom of research guaranteed by the constitution. ${ }^{24}$ Nor does the doctrine of the fruit of the poisonous tree, which is of great importance in the ethics debate, as such have a place in a constitutional discussion about possible restrictions of the freedom of research. In the opinion of other writers, ${ }^{25}$ however, the restrictions of the Stem Cell Act create a "post-mortem protection of the human dignity of prenatal life." ${ }^{26}$ But this view is not convincing either. Admittedly, the Federal Constitutional Court has in fact recognised postmortem protection of human dignity as such in several decisions, ${ }^{27}$ but this protection is linked to the fact that the person in question lived and worked in the human community ("among us"). In essence, therefore, this protection concerns the memory of someone who was part of a social community. This idea, however, cannot be transferred to embryos in vitro.

In addition, a state's legal system is not responsible for the protection of legal interests situated abroad in the same way as it is for those within the country. ${ }^{28}$ This shows a

21 See Dederer, supra note 19, at 305, 307; Johanna Raasch, Das Stammzellgesetz-ein beladenes Gesetzesvorhaben, 35 KRITISCHE JUSTIZ 285, 294 (2002); Jochen Taupitz, Import embryonaler Stammzellen. Konsequenzen des Bundestagsbeschlusses vom 31-1-2001, 35 ZEITSCHRIFT FÜR RECHTSPOLITIK 111, 113 (2002).

${ }^{22}$ BT $14 / 8394$ at 7.

${ }^{23}$ BT $14 / 8394$ at 9.

${ }^{24}$ See BT $16 / 7983$ at 2 (coming to a different result); see infra Part A.VI.

${ }^{25}$ See BREWE, supra note 5, at 109 (providing further references). Contra Dederer, supra note 19, at 305, 308-

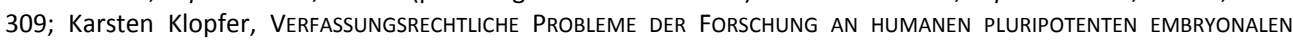
STAMMZELLEN UND IHRE WÜRdigUng IM STAMMZELLGESETZ 83 (2006); Taupitz, supra note 20, at 11, 13.

${ }^{26}$ The expression comes from Löwer, Written Opinion of 8 March 2002, BT 14/574 (Committee on Education, Research and Technology Assessment of the German Bundestag); he himself speaks of "constitutionally absolutely unsecured terrain."

27 See BVerfGE 30, 173 (194); BVerfG, 47 NeUE JURISTISCHE WoChEnSChrift 783, 784 (1994); BVerfG, 54 NeUE JURISTISCHE WOCHENSCHRIFT 594 (2001); BVerfG, 54 NEUE JURISTISCHE WOCHENSCHRIFT 2957, 2958-2959 (2001).

28 See nationaler Ethikrat, Zur Frage einer Änderung des Stammzellgesetzes 40 (2007); Michael Kloepfer, Humangentechnik als Verfassungsfrage, 57 JURISTENZEITUNG 417, 426 (2002); Klopfer, supra note 25, at 81; Ralf Müller-Terpitz, Die neuen Empfehlungen der DFG zur Forschung mit menschlichen Stammzellen, 34 WISSENSCHAFTRECHT: WISSENSCHAFTSVERWALTUNG, WISSENSCHAFTSFÖRDERUNG 271, 279-280 (2001); Jochen Taupitz, Der "ethische Export" als Rechtsproblem biomedizinischer Forschung, dargestellt aus dem Blickwinkel des deutschen

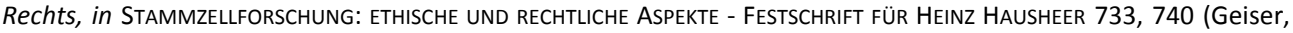
Koller, Reusser, Walter \& Wiegand eds., 2002). For a more restrictive view, see BREWE, supra note 5 at 98. 
fundamental difference between law and morality: whereas morality and ethics are universally oriented, law (apart from international law) is based on the idea of state sovereignty. This does not exclude protection of universal legal interests. In addition, the states are required to pursue the violation of legal interests which are recognised in all civilised states, irrespective of the territory and the nationality of the perpetrator (universality principle). International law too, is based on the principle of worldwide application. But the global legal community (Weltrechtsgemeinschaft) has no common understanding of the appropriate protection of embryos in vitro, as the varying provisions show. ${ }^{29}$ For this reason, if embryos are destroyed abroad without any relation to Germany, this does not make it mandatory that the use of the stem cells derived from the embryos should subsequently be subject to restrictive conditions in Germany. Against the background of these arguments, a considerable number of authors regard the restrictions of the Stem Cell Act which exceed the cutoff date provision as unconstitutional. ${ }^{30}$

\section{No Legalisation of the Past Destruction of Embryos}

In all the above provisions, the Stem Cell Act does not pronounce that the derivation of embryonic stem cells abroad is legal. Nor does the Stem Cell Act place eminent research above the protection of the life of embryos. Instead, the Act merely permits the importation and use of stem cells which were derived in the past, which means that the utilisation of embryos entailed in this occurred in the past and cannot be reversed. As long as the importation and use of those stem cells are permitted which were derived in compliance with the legal position in the country of origin ( $\$ 4$ (2) no. 1 a) SCA), it is to be particularly emphasised that the question as to whether and subject to what requirements destructive embryo research is permitted or prohibited abroad is to not be judged by German law, but by the relevant foreign law. ${ }^{31}$

The attitude of the legislator in, on the one hand, rejecting the derivation of stem cells, but on the other hand authorising the importation and use of embryonic stem cells (albeit subject to very strict requirements) is unobjectionable from a constitutional point of view (A.V. above). However, this is criticised as "morally lazy" or as an expression of "double moral standards." 32 it is claimed that it is "absolutely unacceptable" to leave foreign

\footnotetext{
${ }^{29}$ See NATIONALER ETHIKRAT, supra note 28, at 40.

${ }^{30}$ See the references supra note 13 (providing evidence). See also the references supra note 25 (providing opposing views).

${ }^{31}$ See BT. $14 / 8846$ at 13 . For constitutional objections to this provision, see BREWE, surpa note 5 , at 167 .

32 See Merkel, forschungsobjekt Embryo, Verfassungsrechtliche und ethische GrundLagen der forschung an

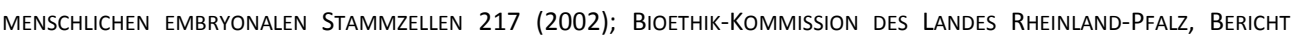
"MEDIZINISCHE, ETHISCHE UND JURISTISCHE BEWERTUNG DER FORSCHUNG AN HUMANEN EMBRYONALEN StAMMZELLEN UNTER EINBEZIEHUNG DES STAMMZELLGESETZES VOM 28. JUNI 2002," 52 (Aug. 23, 2002); Raasch, supra note 21, at 285, 294-295
} 
researchers to carry out the derivation of embryonic stem cells which is rejected in Germany, while at the same time making use of the results. In this context, it is not uncommon (but questionable) ${ }^{33}$ for a parallel to be drawn to receiving stolen goods. Others point out that it is arbitrary to lay down a fixed date from which henceforth the doctrine of the fruit of the poisonous tree applies; one should either always take the standpoint that its wrong to eat the fruit of the poisonous tree, or one should reject this principle. $^{34}$ However, moral objections to the use of the fruit of past wrong do not per se exclude every weighing of interests whatsoever. They may be subordinated if the use serves eminent interests and goals, for example the treatment of serious illnesses. ${ }^{35}$ Thus assisted reproduction, which is now firmly established in Germany, was and is based on knowledge arising from destructive embryo research undertaken in other countries. ${ }^{36}$ Quite generally, it is certainly necessary to distinguish between an act that produces something and an act that merely uses the product. ${ }^{37}$

In addition, there is the following problem: even the strict German Embryo Protection Act does not prohibit destroying embryos as such. Where embryos - for whatever reason cannot be transferred to a woman for the purpose of reproduction, there is no requirement to preserve them. It is therefore undisputed that there is no obligation to keep them alive; they may be disposed of ${ }^{38}$. It is to be doubted whether the disposal constitutes a violation of human dignity, solely because the embryos are not merely "disposed of", but additionally used to derive stem cells. This can scarcely be regarded as a "scornful disparagement" according to the judicature of the Federal Constitutional Court. This applies independently of the controversial question as to whether embryos in vitro should be seen as deserving protection of human dignity at all (and if so, in what intensity). The Stem Cell Act, in turn, permits at most the importation and use of stem cells from such embryos which - because they could not be transferred to a woman - anyhow had no real

(2002); Ulrich Schroth, Forschung mit embryonalen Stammzellen und Präimplantationsdiagnostik im Lichte des Rechts, 57 JURISTENZEITUNG 170, 178 (2002).

\footnotetext{
${ }^{33}$ See NATIONALER ETHIKRAT, supra note 28, at 18-19. The need to sanction receiving stolen goods usually follows from the mere fact that it has a causal effect on the perpetuation of robbery and theft, which cannot normally be assumed of the use of stem cells produced abroad; apart from this, receiving stolen goods requires prior criminal acts which are without doubt ethically and legally condemned everywhere; but this is decidedly not the case with regard to the production of embryonic stem cells, since this is permitted in many countries.

${ }^{34}$ Ulrich Schroth, Forschung mit embryonalen Stammzellen und Präimplantationsdiagnostik im Lichte des Rechts, in STAMmZellenforschung UND theRAPEUTISCHES KLonen 249, 280 (Oduncu, Schroth \& Vossenkuhl eds., 2002).

${ }^{35}$ See NATIONAler EthiKRAT, supra note 28, at 19.

${ }^{36}$ See id.

${ }^{37}$ Taupitz, supra note 12 , at $113,118$.

${ }^{38}$ HANs-LudWIg GÜnther, Jochen TAUPItZ \& Peter KaIser, EmbryonenschutzgeSetZ, § 1 Abs. 1 Nr. 3 margin note 7 (2008).
} 
chance of life. Since, therefore, even the original act of using the embryo does not constitute an obviously serious injustice, it must all the more be doubted whether the act of exploitation, that is, the use of embryonic stem cells, can be disapproved of in itself.

It may, however, be established that the Act, against the background of the starkly diverging views, has at least made an important contribution to social pacification, which has existed for quite a time. ${ }^{39}$

\section{Procedural Protection}

Two institutions are competent to review the above material requirements: every importation and every use of embryonic stem cells must be approved by the Robert KochInstitute. ${ }^{40}$ Its approval depends not only on the above-named requirements of s. 4 (2) SCA; in addition, there must also be an opinion given by the Central Ethics Commission for Stem Cell Research (Zentrale Ethikkommission für Stammzellforschung), whose members are representatives of biology, medicine, ethics and theology. The Central Ethics Commission for Stem Cell Research for its part must (only) review whether the requirements of S. 5 SCA (eminent research with no alternatives) are satisfied and the research project is ethically justifiable in this sense. ${ }^{41}$

\section{B. Reform discussion and suggested legislation prior to the Bundestag decision of $\mathbf{1 1}$ April 2008}

\section{Cutoff Date Provision}

The much-discussed original cutoff date (1 January 2002) was fixed to be earlier than the date when the Act came into force (1 July 2002). The intention was to prevent destruction of embryos "on order" proceeding from Germany. ${ }^{42}$ But by laying down a fixed cutoff date lying in the past (as in the case of the new cutoff date-on this, see C. below), the legislator went too far. This is because it also excludes acts which are only distantly or not at all responsible for causing the destruction of embryos. There is no concrete legal attribution of a particular causal element. Consequently, a researcher has no possibility of proving

\footnotetext{
${ }^{39}$ Stephan Roesler, Das deutsche Stammzellgesetz-Spezifische Fragen der Auslegung des Gesetzes, in JAHRBUCH FÜR WISSENSCHAFT UND ETHIK 283 (2003).

${ }^{40}$ This follows from $\S 6$ SCA in conjunction with the delegated legislation supplementing the Stem Cell Act.

${ }^{41}$ On the scope of the Commission's powers of review, see BREWE, supra note 5, at 224; Jochen Taupitz, Die Aufgaben der Zentralen Ethikkommission für Stammzellforschung, in FESTSCHRIFT FÜR HANS-LUDWIG SCHREIBER, 903 (Amelung, Beulke, Lilie, Rosenau, Rüping \& Wolfslast eds. 2003).

${ }^{42}$ Zentrale Ethikkommission bei der Bundesärztekammer, Stellungnahme zur Stammzellforschung vom 19.6.2002 (Opinion on stem cell research of 19 June 2002 of the Central Ethics Commission at the German Medical

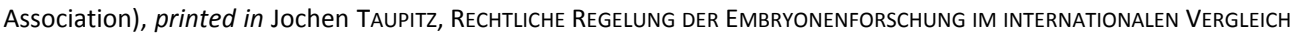
233, 269 (2003); See also the legislative rationale on the draft Stem Cell Act of 27 February 2002, BT 14/8394 at 9.
} 
that no embryo was destroyed specifically as a result of him ordering the stem cells. Instead, the Act is based on the general suspicion that every destruction of an embryo in order to derive embryonic stem cells after the cutoff date has been ordered from Germany if these stem cells are then used for German research.

The constitutionality of the cutoff date provision is and was the subject of intensive discussion. The opinion is expressed that the cutoff date provision is necessary in the interest of the greatest possible protection of life. ${ }^{43}$ In addition, it is said that there are no objections to it with regard to the prerogative of assessment and drafting which the Federal Constitutional Court grants the legislature. According to this opinion, adapting the cutoff date to a later date ("flexible cutoff date") would not achieve the legislator's aim in an equally suitable manner. However, this opinion is not convincing. The cutoff date provision, within the system of the legislation (prohibition subject to approval), is an exception to the prohibition of importation and use, but at the same time de facto prohibits the importation and use of all embryonic stem cells produced after the cutoff date. As set out above, this is intended to prevent (indirectly, that is, by preventing sale to Germany) a (further) destruction of embryos being brought about from Germany. But precisely this is already directly guaranteed by the Embryo Protection Act in conjunction with the provisions of international criminal law ( $\S \S 3$ to 7, 9 of the German Criminal Code (Strafgesetzbuch - StGB)). This provides that every participation of German researchers from Germany in stem cell derivation abroad is prohibited and a criminal offence, even if the act is not a criminal offence in its location. ${ }^{44}$ All that the cutoff date provision in the Stem Cell Act and the associated prohibition of importation and use do is to additionally catch cases in which foreign researchers or enterprises produce hES cells on their own initiative, but are motivated by the expectation of later demand from Germany, and with the intention of then exporting them to Germany. However, this case is somewhat far from reality. There is a global demand for embryonic stem cells. In addition, the existing cell lines can be kept in culture for a very long time and can be propagated at will. Thus, it cannot be assumed that additional embryos are destroyed or have to be destroyed specifically to satisfy the need for stem cells in Germany. ${ }^{45}$ Altogether, therefore, a

${ }^{43}$ Kurt Faßbender, Der Schutz des Embryos und die Humangenetik: Zur Verfassungsmäßigkeit des neuen Stammzellgesetzes und des Embryonenschutzgesetzes im Lichte des einschlägigen Arzthaftungsrechts, 21 Medizinrecht 279, 283 (2003).

${ }^{44} \S 5$ no. 12 StGB contains even stricter provisions for German public officials. This also applies in particular to members of universities, but also to members of quasi-governmental non-university institutions. See Albin Eser \& Hans-Georg Koch, Forschung mit humanen embryonalen Stammzellen im In- und Ausland; Eser \& Koch, Forschung mit humanen embryonalen Stammzellen: Strafrechtliche Grundlagen und Grenzen, in DEUTSCHE FORSCHUNGSGEMEINSCHAFT 37, 151 (2003).

${ }^{45}$ See NATIONAler ETHiKRAT, supra note 28, at 16, 41-42; Zentrale Ethikkommission, supra note 42, at 233, 269;

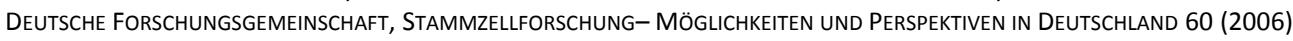
available

http://www.dfg.de/aktuelles_presse/themen_dokumentationen/stammzellen/dfg_publikationen_stammzelforsc hung.html; see also Klopfer, supra note 25 at 85-86. 
connection between the number of embryonic stem cells used in Germany and the number of embryos destroyed abroad is extremely questionable. ${ }^{46}$ In other words, the Stem Cell Act causes great detriment to research in Germany, without in turn creating protection of foreign embryos extending beyond the Embryo Protection Act. ${ }^{47}$ In constitutional terms, this means that the prohibition of importation and use of the Stem Cell Act in conjunction with the cutoff date provision entails a disproportionate encroachment upon the freedom of research. ${ }^{48}$

The situation worsened due to the fact that the factual effects of the cutoff date provision were increasingly reaching towards a complete prohibition of research before the revision of the Stem Cell Act in 2008:

(1) This results from the fact that the "old" hES cells, which were derived before the original cutoff date (1 January 2002), are of a considerably inferior quality. Unlike the "new" hES cells, they were cultivated on layers of animal cells and thus cannot be used therapeutically due to a serious risk of infection should they be used on human beings. Because of this, the research work that has been approved may have to be repeated with other stem cells, either later or at another location, because the characteristics of the cells which comply with the old cutoff date provision may differ from those of the cells later used in the clinic. ${ }^{49}$ The interest of German enterprises in investing in stem cell research was therefore very limited.

(2) The stem cell lines produced before 1 January 2002 were not isolated and cultivated under standardised conditions pursuant to the rules of good laboratory practice or good manufacturing practice. Further, suboptimal culturing conditions have in part resulted in genetic and epigenetic changes. The expression patterns and development stages of the stem cell lines produced before 1 January 2002 are therefore very heterogeneous. This too has a detrimental effect on their suitability for basic research, and all the more for later clinical and therapeutical use on humans.

\footnotetext{
${ }^{46}$ E.g., Claus Dieter Classen, Die Forschung mit embryonalen Stammzellen im Spiegel der Grundrechte, 117 DEUTSCHES VERWALTUNGSBLATT, 141, 147 (2002).

${ }^{47}$ See id. at 147 ("[The German legislator, in prohibiting the importation of embryonic stem cells] does not in principle ... make a genuine contribution to the protection of embryos.").

${ }^{48}$ See Schroth, supra note 34, at 249, 280; Klopfer, supra note 25, at 85; see also Friedhelm Hufen, Erosion der Menschenwürde?, $59 \mathrm{JZ}$ 313, 318 (2004).

${ }^{49}$ See the fears of this of the Zentrale Ethikkommission für Stammzellforschung (Central Ethics Commission for Stem Cell Research), Dritter Bericht vom 14.12.2005, 6, available at http://www.rki.de/cIn_011/nn_228928/DE/Content/Gesund/Stammzellen/ZES/Taetigkeitsberichte/taetigkeitberi cht-inhalt.html
} 
(3) The importation of hES cells produced abroad before 1 January 2002 makes researchers in Germany dependent on foreign patents and licences. Detailed material transfer agreements usually make sure that the research results obtained with the imported cell lines are (co-)owned by the producers. In addition, there is an obligation to disclose unpublished data to the producing enterprise too. There are, however, now a number of new cell lines which have been made freely available to science, so can be used without accepting these restrictions. However, German researchers could not use these freely available cell lines, because they were not produced before 1 January 2002. So the cutoff date provision very substantially fortified foreign monopolies. Another result of this is that the authoritative standards were laid down abroad. But above all, German enterprises were discouraged from investing in stem cell research. This is because later commercial applications were normally covered by the foreign patent, and there could therefore be scarcely any expectation of profit in Germany. The lack of commercial prospects, in turn, had negative effects on the development of basic research itself.

(4) The cutoff date provision resulted in considerable problems in international cooperations because there was an extremely high risk that criminal offences would be committed by German and foreign researchers in collaborative projects where work was done using "new" stem cell lines. Consequently, German researchers scarcely ever succeeded in being involved in international cooperations or in obtaining foreign researchers to cooperate on joint projects. A large number of opinions and reports referred insistently to the problem of the increasing international isolation of German researchers, for example that of the Central Ethics Commission at the German Medical Association, ${ }^{50}$ the Association of the Scientific Medical Societies in Germany (Arbeitsgemeinschaft der Wissenschaftlichen Medizinischen Fachgesellschaften), ${ }^{51}$ the Central Ethics Commission for Stem Cell Research, ${ }^{52}$ the Bio-Ethics Commission of the Land Rhineland-Palatinate (Bioethik-Kommission des Landes Rheinland-Pfalz), ${ }^{53}$ the $\mathrm{GRF}^{54}$ and

\footnotetext{
${ }^{50}$ See Zentrale Ethikkommission, supra note 42, at 233, 270.

${ }^{51}$ See Arbeitsgemeinschaft der Wissenschaftlichen Medizinischen Fachgesellschaften [Association of the Scientific Medical Societies in Germany], Opinion of 11 July 2003, available at http://www.uniduesseldorf.de/WWW/AWMF/res/res-estz.htm.

${ }^{52}$ See Zentrale Ethikkommission für Stammzellforschung, supra note 49, at 6.

${ }^{53}$ See Bioethikkommission Rheinland-Pfalz, Fortpflanzungsmedizin und Embryonenschutz of 12 December 2005, 71-72, 115.

${ }^{54}$ See Deutsche Forschungsgemeinschaft, supra note 45, at 5, 52.
} 
the German National Ethics Council. ${ }^{55}$ The German Bundestag also considered this problem as early as in $2005 .^{56}$

Admittedly, at the time the cutoff date provision was probably the only political possibility of continuing with at least a small part of basic research. In fact, over time it has resulted in a nearly complete prohibition of research with hES cells in Germany. ${ }^{57}$ This consequence is constitutionally more than questionable: the constitutional mandate of protection of embryos situated abroad is indisputably unlike that of embryos situated in Germany. ${ }^{58}$ And still, it is the declared goal of the Stem Cell Act itself not to completely prevent stem cell research in Germany, yet it is an effect created by the Act itself which is, equivalent to a prohibition, inconsistent with that goal.

From the point of view of legal policy too, the cutoff date came under increasing pressure as it became clear that German researchers were cut off from international progress. Thus, for example, the FDP parliamentary group in the German Bundestag as early as in $2005^{59}$ and the German Research Foundation in $2006^{60}$ called for the cutoff date to be abolished, while the literature also called for a "flexible" cutoff date. ${ }^{61}$ In the year 2007, the German National Ethics Council suggested that the cutoff date should be replaced, and instead to consider each case individually in order to judge whether the derivation of stem cells was initiated from Germany or not. ${ }^{62}$

\section{Risks of Criminal Liability in International Collaborative Research}

A serious problem of the original Stem Cell Act was, as mentioned above, the possible criminal liability of German and foreign researchers if they were involved in international collaboration (for example in the Sixth or Seventh EU Framework Programme). §13 (1) SCA reads as follows: "Any person who imports or uses embryonic stem cells without approval

\footnotetext{
${ }^{55}$ See supra NATIONALER ETHIKRAT, note 28 , at $31 \mathrm{ff}$.

${ }^{56}$ Minor interpellation of the FDP parliamentary group of 15 March 2005 on the cooperation of German scientists with foreign scientists in EU stem cell research projects, BT 15/5165; Answer of the Federal Government of 30 March 2005, BT 15/5196.

${ }^{57}$ For this case at all events, the legislator's solution was described as unconstitutional immediately after the provision entered into effect: Kloepfer, supra note 28, at 427 (2002); Raasch, supra note 21, at 285, 294.

${ }^{58}$ See supra note 28 .

${ }^{59}$ Motion of the FDP Parliamentary Group of 18 January 2005, BT 16/383; Motion of the FDP Parliamentary Group of 1 June 2005, BT 15/5584.

${ }^{60}$ See DEUTSCHE FORSCHUNGSGEMEINSCHAFT, supra note 45 at 7, 50-51.

${ }^{61}$ Taupitz, supra note 12 , at $113,117-118$.

${ }^{62}$ See NATIONALER ETHIKRAT, supra note 28 , at 51.
} 
pursuant to $\S 6$ (1) shall be liable to imprisonment of up to three years or to a fine." It was disputed whether "use" only means "use within Germany" and whether the general system of criminal law on liability for involvement in acts abroad also applied, as a result of which a researcher who collaborated from within Germany with another researcher, who legally carried out stem cell research abroad, was also criminally liable.

The literature increasingly and correctly held up the opinion that the area of application of the Stem Cell Act was restricted from the outset to German territory, since only import into Germany and use in Germany could be approved. ${ }^{63}$ Following this opinion thoughcontrary to the discussions in the course of deliberation on the $\mathrm{Act}^{64}$ - participation (instigating or aiding and abetting) in the use of embryonic stem cells abroad was not punishable under $\S 13$ SCA in conjunction with $\S 9$ (2) German Criminal Code. For if the principal offence in which the instigator or accessory participates can, by reason of the restricted territorial application of the Stem Cell Act, only be committed in Germany, then participating in an act abroad cannot be a criminal offence. However, the uncertainty remained as to whether this interpretation of the Stem Cell Act- which was certainly not undisputed ${ }^{65}$ - would also be shared by the courts. In addition, even according to this opinion, there remained the risk of criminal liability for joint commission and indirect commission. This is because under the general system of criminal law, an accomplice in Germany is also held liable for a contribution of his or her own to an act which is committed abroad. ${ }^{66}$ This risk existed in particular in the case of close collaboration, by sharing work with a person researching abroad (legally under the foreign law). Consequently, a German researcher commits an offence under the German Stem Cell Act if the foreign researcher he was collaborating with worked with embryonic stem cells abroad, even if the foreign researcher worked in accordance with the local law. The international exchange of scientists also carried a particular risk of criminal liability under $\$ 5$ no. 12 or no. 13 German Criminal Code if they were "officials" or "persons with particular obligations for the civil service." ${ }^{\prime 7}$ If German criminal law was to be interpreted broadly, in some circumstances even foreign researchers, working with stem cells abroad, committed criminal offences under the German Stem Cell Law. ${ }^{68}$ This all resulted in considerable uncertainty among German and foreign scientists, and as a result the

\footnotetext{
${ }^{63}$ See Eser \& Koch, supra note 44, at 118; Dahs \& Müssig, Forschung mit humanen embryonalen Stammzellen im In- und Ausland in DeUTSCHE ForSChUngSGEMEINSCHAFT, note 44, at 18; BREWE, supra note 5, at 250.

${ }^{64}$ For a more detailed treatment, see BREWE, supra note 5, at 251-252.

65 For a different view, see, e.g. Eric Hilgendorf, Strafbarkeitsrisiken bei der Stammzellforschung mit Auslandskontakten, 39 ZEITSCHRIFT FÜR RECHTSPOLITIK 22, 23-24 (2006).

${ }^{66}$ See Eser \& Koch, supra note 44, at 136; Hilgendorf, supra note 65, at 24 (2006).

${ }^{67}$ See Eser \& Koch, supra note 44, at 151.

${ }^{68}$ See Hilgendorf, supra note 65, at 24 (2006).
} 
international competitiveness of German researches and their ability to collaborate was increasingly called into question (B.I. above). In its opinion of November 2006, the GRF pointed out that it knew of examples of scientists who deliberately avoided this area of research or had withdrawn from it, because of what they thought was a lack of prospects and because embryonic stem cell research was frequently discredited in Germany. ${ }^{69}$ The Opinion stated that this was not only reflected in the relatively small number of applications made, but also in the global comparison of the number of publications on the subject: German researchers were virtually unrepresented.

It was widely argued that legal certainty would be attained if it were made clear both in $\S 2$ SCA and in \$13 SCA that the Stem Cell Act relates only to the use of stem cells located in Germany. ${ }^{70}$ In addition, the German National Ethics Council called for the provision of $\S 13$ SCA, which created a criminal offence, to be downgraded into one creating a regulatory offence. ${ }^{71}$ The demands of the GRF went even further: ${ }^{72}$ it called for $\S 13$ SCA to be completely discarded.

\section{The Restriction of the Use of Stem Cells to Research Purposes}

Although stem cell research is above all intended to serve the purpose of developing new therapies, the prohibition of the use of hES cells for every purpose except narrowly defined research prohibits their use for diagnostic, therapeutic and preventive purposes. This prohibition also applies to individual attempts to achieve a cure, which normally precede clinical trials (which themselves constitute research) ${ }^{73}$ and all the more precede the use of tested therapies in clinical practice. The restriction of the importation of stem cells for research purposes was and is therefore criticised as short-sighted and inconsistent. ${ }^{74}$ There are calls to permit the use of human embryonic stem cells for health-related purposes too. Failing this, German research - as the Central Ethics Commission for Stem Cell Research complained - will remain restricted "to creating fundamental principles for the future use of the cells for therapeutic, preventive and diagnostic purposes outside

\footnotetext{
${ }^{69}$ See Deutsche Forschungsgemeinschaft, supra note 45 at 54.

${ }^{70}$ See NATIONALER ETHIKRAT, supra note 28 , at 47-48.

${ }^{71}$ See NATIONALER ETHIKRAT, supra note 28 , at 48-49, 51-52.

${ }^{72}$ See supra Deutsche Forschungsgemeinschaft, opinion "Stammzellforschung - Möglichkeiten und Perspektiven in Deutschland", note 45 at 8, 61-62.

${ }^{73}$ Clinical trials are permissible under the SCA; so also argued in Ralf Müller-Terpitz, Humane Stammzellen und Stammzellderivate, in JAHRBUCH FÜR WISSENSCHAFT UND ETHIK 79, 90-91 (2006).

${ }^{74}$ See Bioethik-Kommission des Landes Rheinland-Pfalz, supra note 53, at 75-76, 115; Zentrale Ethikkommission für Stammzellforschung, supra note 49, at 4; DEUTSCHE FORSCHUNGSGEMEINSCHAFT, supra note 45 at 7, 61-62; BREWE, supra note 5, at 198-199; Klopfer, supra note 25, at 89-90; Raasch, supra note 21, at 293; Schroth, supra note 34, at 249, 280; Taupitz, supra note 21, at 104.
} 
Germany." ${ }^{75}$ But also this contribution to research will increasingly atrophy, as the Stem Cell Act prevents the indispensable cooperation of scientific research and clinic application. ${ }^{76}$ However, an extension of the legitimate uses is problematical because it can scarcely be implemented while the current requirement of official approval of every "use" continues to be in effect. It is therefore understandable that the discussions in parliament (C. below) have excluded this point.

\section{The Prohibition of the Importation of Stem Cells from Intracorporeally Fertilised Embryos}

Under $\S 4(2)$ no. 1 b) SCA, the imported stem cells may not have been derived from intracorporeally fertilised embryos (A.III. above). No plausible justification can be seen for such embryos not being used for the derivation of stem cells, provided that the other requirements of the Stem Cell Act are satisfied. ${ }^{77}$ Nor is it supplied in the legislator's statement of intention. The literature therefore calls for this restriction to be removed. ${ }^{78}$

\section{The Prohibition of the Importation of Stem Cells from Embryos That Were Not Created By Way of Fertilisation}

HES cells offer the opportunity of analysing development processes of diseases on the cellular level by establishing cell lines from embryos that carry genetic defects which cause specific diseases. These cells also make it possible to test new medicinal products in vitro before they are used on human beings. New hES cell lines established since the cutoff date are now available to investigate thalassemia, Huntington's disease, muscular dystrophy and other genetic disorders. ${ }^{79}$ They were either created by the method of cell nuclear transfer or derived from embryos which were not transferred to the mother as the result of a PID. However, $\S 4$ (2) no. 1 b) SCA provides that such cells may not be imported into Germany (A.III. above). As a result, research using these disease-specific hES cells is prohibited in Germany. And yet, precisely such research would be desirable, not least in pharmacogenetics or toxicity testing, because it avoids endangering patients. Here too there are calls in the literature to relax the restrictions of the statute, ${ }^{80}$ but no activity in parliament to date.

\footnotetext{
${ }^{75}$ See Zentrale Ethikkommission für Stammzellforschung, supra note 49 , at 6 .

${ }^{76}$ See Klopfer, supra note 25 , at 90.

${ }^{77}$ See Raasch, supra note 21, at 294.

${ }^{78}$ See Taupitz, supra note 12 , at 120.

${ }^{79}$ See Deutsche Forschungsgemeinschaft, supra note 45, at 34-35.

${ }^{80}$ Taupitz, supra note 12 , at $120-121$.
} 


\section{Parliamentarian Initiatives Resulting in the Decision of the German Bundestag of 11 April 2008}

In spring 2008, five bills were introduced to the German Bundestag proposing an amendment of the Stem Cell Act. The bills reflect the whole spectrum of opinions found in Germany on the question of the permissibility of research with embryonic stem cells. The most radical proposa $\left.\right|^{81}$ called for both the cutoff date provision and the criminal provision of the Act to be repealed without replacement. But this would not have corresponded to the logic of the Act (although it would be constitutional). The less radical second proposal $^{82}$ provided for the cutoff date to be changed to 1 May 2007; further, it also restricted the area of application of the Act as a whole and also of the criminal provision expressly (in addition to importation) to embryonic stem cells that are situated "in Germany." This was intended to counteract the considerable legal uncertainties with regard to the risk of criminal liability in international cooperations arising from the previous version of the Act (B.II. above). The third bill ${ }^{83}$ provided for the same restriction to embryonic stem cells situated in Germany, but it did not alter the cutoff date. A fourth proposal, ${ }^{84}$ in contrast, called for the existing legal position to remain unchanged and for the promotion of research using adult stem cells. Finally, a fifth proposal ${ }^{85}$ called for a complete prohibition of the importation and use of embryonic stem cells, because research with them was unnecessary and no therapeutic uses could be foreseen.

On 11 April 2008, the German Bundestag, after intensive discussion, voted in favour of the second proposal (Bundestag printed paper 16/7981), by a clear majority of 346 votes to 228 votes with 6 abstentions. ${ }^{86}$ As a result, the cutoff date was moved to 1 May 2007 and the area of application of the Act as a whole and also of the criminal provision was expressly restricted to the importation of embryonic stem cells and the use of embryonic stem cells that are situated "in Germany."

\footnotetext{
81 See Entwurf eines Gesetzes für eine menschenfreundliche Medizin - Gesetz zur Änderung des Stammzellgesetzes, BT 16/7982.

${ }^{82}$ See Entwurf eines Gesetzes zur Änderung des Stammzellgesetzes, BT 16/7981.

${ }^{83}$ See Entwurf eines Gesetzes zur Änderung des Stammzellgesetzes, BT 16/7984.

${ }^{84}$ See Keine Änderung des Stichtages im Stammzellgesetz-Adulte Stammzellforschung fördern, BT 16/7985.

85 See Entwurf eines Gesetzes zur Änderung des Gesetzes zur Sicherstellung des Embryonenschutzes im Zusammenhang mit menschlichen embryonalen Stammzellen, BT 16/7983.

${ }^{86}$ Second and Third Reading, Bundestagsprotokolle (Minutes of Bundestag Plenary Proceedings), BT 16/155; the first reading of the bills took place on 14 February, BT 16/142. In its session 844 of 23 May 2008, the Bundesrat rejected the motion of Bavaria of 20 May 2008, BUNDESRAT DRUCKSACHEN [BR] 278/08, for an appeal to the Mediation Committee (Vermittlungsausschuss).
} 
The alteration of the cutoff date is completely in compliance with the basic intention of the Stem Cell Act (A.Il. above). It is also in compliance with the view, which is also rightly expressed in the Stem Cell Act, that acts of exploitation must be evaluated differently from acts of production and that (assumed) injustice in the past is not undone or eliminated by a prohibition of the act of exploitation. In addition, the original Act already contained the possibility of an amendment to the Act by changing the cutoff date. The duty to provide information, which was and is imposed on the Federal Government by in $\S 15$ SCA, ${ }^{87}$ can have no other purpose than to permit the experience gained in the implementation of the Act to be incorporated, where appropriate, in discussions on an amendment of the Act. Otherwise, the report called for would not need to be provided to the German Bundestag, which has sole responsibility for the amendment of the Act.

However, it is not very convincing that a cutoff date relatively far in the past (1 May 2007) was chosen; this holds true regarding the date when the amendment to the Act was passed (11 April 2008), as well as the date when it entered into effect (21 August 2008). ${ }^{88}$ The date 1 May 2007 was clearly chosen because there was a hearing in the Committee on Education, Research and Technology Assessment of the German Bundestag on 9 May $2007^{89}$ and this was obviously regarded as the starting signal for the discussions in parliament on an amendment of the Stem Cell Act. However, it cannot seriously be assumed that in the following months even one single stem cell line was produced abroad because there was a discussion in Germany in May 2007 on an amendment to the Stem Cell Act with the possibility of the cutoff date being changed or removed as a consequence. Firstly, it should be obvious even to every foreign researcher that a discussion - on an extremely controversial issue - in a committee of the German Bundestag does not automatically result in a statute. And secondly, the significance of the German market (as is shown by the small number of research projects carried out here to date) is not likely to be so great that it gives a notable impetus to the production of embryonic stem cell lines abroad. It must therefore again be emphasised that the unconstitutionality is all the more tangible the further the cutoff date lies in the past, even then if it is in fact moved, but on the date when the amendment to the Act enters into effect, it is still a considerable time in the past.

The clarification concerning the application of the Act and its criminal provision, that is, the specific restriction of the prohibition of a use of hES cells to those that are located in

\footnotetext{
87 "The Federal Government shall submit to the Deutscher Bundestag a report presenting the experience gained with the implementation of the present Act every two years, beginning the end of 2003. The report shall also describe the results of research using other types of human stem cells."

${ }^{88}$ The Act was promulgated in the Bundesgesetzblatt (Federal Law Gazette) on 20 August 2008 and pursuant to its Article 2, it therefore entered into effect on 21 August 2008.

89 Protokoll 16/53 des Ausschusses für Bildung, Forschung und Technikfolgenabschätzung des Deutschen Bundestages, BT 16/53.
} 
Germany is more than welcome. The full implications of the uncertainties in relation to the risk of criminal liability (B.I. above) were clearly not fully understood when the Act was passed. In addition, it can also be assumed that this was not desired at the time and that "use" was to be interpreted as use in Germany. The amendments therefore correspond to the fundamental intention of the Stem Cell Act: to deal with the importation of stem cells and also with their use in Germany.

\section{Final Remarks}

(1) In the discussions in parliament, there was and is clearly an agreement that the Embryo Protection Act is not to be touched. This means that the production of embryonic stem cells will continue to remain prohibited in Germany.

(2) The political discussion on the law of embryonic stem cell research will continue in Germany. In the near future, it will, above all others, be the turn of the scientists to speak. It will depend on their research results whether research using human embryonic stem cells will continue to be seen as necessary, whether it must even be expanded or whether, on the contrary, it will become obsolete and it will retrospectively be seen that Germany made the right decision in taking a position that is extremely restrictive in comparison to that of other countries.

(3)The Stem Cell Act relates to a rather small area of biomedical research. However, it clearly has symbolic significance far exceeding its concrete area of application. This is the only explanation for the violent discussion, sometimes accompanied by a great deal of emotion. However, it is inappropriate to stir up fears in the population with the argument that the destruction of embryos will soon be followed by the killing of humans already born, for example old people and sick people, for the purposes of research. Such an argument ignores the ability of a society to differentiate - and the responsibility of parliament as the legislator. Significantly, the liberalisation of abortion law did not lead to a weakening of the right to life of human beings already born. This also applies with regard to the permissibility of an abortion of defective embryos and foetuses. On the contrary: the sensitisation of society for the needs of people with disabilities has increased, possibly even because embryos and foetuses in the womb do not have an absolute right to life. 